\title{
Exploration of low-carbon rural tourism in zhejiang: A Case Study of Tian Mu Village, Lin an County
}

\author{
Jian Qiang HU ${ }^{1,2, a}$, Chu Yuan LOU ${ }^{1}$, and Ling WANG ${ }^{1}$ \\ ${ }^{1}$ School of Modern Service, Zhejiang Shuren University, Hangzhou, 310015, China; \\ ${ }^{2}$ The Research Center of modern service industry of Zhejiang Province, Hangzhou, 310015, China
}

\begin{abstract}
Along with the advancement of the construction of ecological civilization, low-carbon economy and low-carbon tourism are increasingly affecting the production and life style of human beings. Low carbon tourism is in the process of tourism development, through the use of low-carbon technologies, promote carbon absorbing mechanism and advocate low carbon tourism consumption to obtain higher tourism experience quality and greater tourism economic, social and environmental benefits of a sustainable development of tourism in new ways . Low carbon has become a recognized future development direction of the tourism industry. Closely linked to this paper, vigorously develop low carbon tourism industry requirements, to Lin an, Zhejiang Tian mu village, for example, through on-the-spot investigation, the problems existed in the village rural tourism low carbon analysis, and put forward the corresponding countermeasures, in order to rural tourism and low-carbon development in our province to find a feasible and with a demonstration of the significance of the road, and for other areas to carry out low carbon tourism experience.
\end{abstract}

Keywords: Low carbon Tourism; Low carbon economy; Rural tourism; Tian mu Village

\section{Introduction}

Rural tourism is based on the farmers' family management, with the characteristics of rural scenery and rural interest, in order to experience the main content of rural life as the main content of leisure travel [1]. The practice of rural tourism in the province, to speed up the beautiful countryside, the construction of ecological civilization, and strive to rural areas to build a "livable industry should swim better homes has played a positive role in promoting [2]. By the end of 2015, the Zhejiang province reported a total development of 3,246 rural tourism villages, 14,840 viable farm units, tourism reception of $183,608,400$ visitors, and annual business income reached 1412 billion yuan. On the whole, however, from the current situation in our province, the various links and processes of rural tourism generally exist the problem of high carbon emissions, which directly affects the sustainable and healthy development of rural tourism [3]. Therefore, the low carbonization of rural tourism becomes a difficult problem in theory and practice.

\section{The problems of the low carbonization of rural tourism}

\footnotetext{
a Jian Qiang HU: hujianqiang2006@qq.com
}

Based on the basic understanding of the dynamic development of the low carbon tourism education, the author selected Zhejiang province rural tourism model village ----Lin an Tian mu village as a case, through field research, personal visits the local tourists, tourism enterprises (mainly the farmhouse, the shop) operators, to further study the problem and Countermeasure of low carbon Tourism education.

Tian mu village is located in Tian mu Mountain National Nature Reserve in the South. Tian mu village has a beautiful environment, farmhouse economy and rich cultural connotation.

Tian mu village has won the "Zhejiang Province farmhouse characteristic model village", the first batch of "Hangzhou city rural tourism demonstration sites", "Hangzhou city comprehensive construction well-off demonstrative village", "Hangzhou Municipal farmhouse leisure tourism Village, Lin an County socialism new rural construction pacesetter Village, Lin an best leisure place" honor, and adopted the "Hangzhou Municipal eco village" acceptance.

In recent years, Tian mu Village with the guide of the local village committee, has done many beneficial 
attempts in building the "Happy farmhouse ", including construct a number of new tourist facilities, continue to strengthen the management of the local environment, such as road sclerosis, river dredging transformation and so on for constantly create a good environment for "Happy Farmhouse " development, while continuing to increase tourism product innovation, improve product efficiency. With the Tian mu village "Happy farmhouse" developed is getting better, the local village committee come to realize that a good ecological environment is an important prerequisite for sustainable development of "Happy farmhouse ", but also the biggest wealth of Tian $\mathrm{mu}$ village. Therefore, the village committee to actively explore the construction of "Happy farmhouse ", but it is also faced with many problems in the low carbonization of rural tourism.

\subsection{Lack of enough attention to low carbonization of rural tourism}

Due to lack the enough understanding to the construction of low-carbon tourism for long time, the local development of rural tourism construction is the pursuit of benefits, and there is a certain spontaneity and blindness, protection of the local ecological environment and resources are in a relatively subsidiary position. According to investigation, so far, Tian mu village has not organized a low-carbon tourism systemic science education activities, Tian mu village rural tourism practitioners' concept of "low carbonization of rural tourism" is not accurate cognition, whether the need to carry out low carbon tourism education also has fudged.

\subsection{Willingness to carry out the low carbonization of rural tourism is not high}

Based on the spot investigation found of Tian mu village, it is not very high for visitors and employees to accept the low carbonization of rural tourism. Most of tourists think that its to enjoy the natural scenery, travel beauty, rather than accept a the low carbonization of rural tourism to Tian mu village. To accept the low carbonization of rural tourism is bound to affect the tourist mood and the quality of tourism. It has following reason to Tian mu village practitioners unwilling to accept a low carbonization of rural tourism: Firstly, their " Happy Farmhouse " has done quite a low-carbon, there is no need to carry out the low carbonization of rural tourism ; The second is that the low- carbon or low carbonization of rural tourism reform needs to spend more equipment cost, the financial pressures leading to its unwilling to accept a low carbonization of rural tourism or simply training ; The third is considering a low carbonization of rural tourism of their Happy Farmhouse development can not play the role of economic efficiency, and therefore unwilling to accept low carbonization of rural tourism.

\subsection{Lack of reasonable planning for low carbonization of rural tourism}

Due to the lack of low carbonization of rural tourism enough attention, Tian mu village committee and the relevant departments are not reasonable planning for the development of low carbon Tourism education. In Tian mu village, part of the rural tourism, there are still rubbish dumped, low carbon tourism practitioners consciousness, imperfect carbon tourism facilities, tourism product development and irrational phenomena. By visiting the Tian mu village committee, the village committee has invested a number of power and money to strengthen the environment management, such as dredging rivers roads, the construction of seven waste transfer station, through various forms of low-carbon environmental advocacy However, due to the " Happy Farmhouse " practitioners cultural level is not high, inadequate attention to environmental protection, low-carbon tourism building did not achieve significant results. The main reason is the lack of low-carbon tourism-related construction personnel on how to conduct a low carbonization of rural tourism system still lacks theoretical understanding.

\section{Countermeasures to solve low carbonization of rural tourism}

The low-carbon tourism is not just a concept, but also a new way of life and travel behavior. It needs tourists, tourism planning and development departments, tourism enterprises, government and tourist -related management department to think and act. According to the development practical of Tian mu village "Happy Farmhouse "and the problem of low-carbon tourism, the author puts forward some countermeasures.

\subsection{Strengthening the importance of low-carbon tourism promotion}

In order to solve the weak low carbon consciousness of tourists and practitioners, the lack of correct understanding of low carbon tourism and other issues, to develop low carbon " Happy Farmhouse " construction of promotional activities, through various forms including promotional pieces, posters, lectures and other forms to enhance " Happy Farmhouse " practitioners to build awareness of the importance of low-carbon tourism , establish a " Happy Farmhouse " building need to support the concept of low carbonization of rural tourism

\subsection{Strengthening the construction of low carbonization of rural tourism system}

Carry out the construction of low carbonization of rural tourism, we must solve the problems of the willing of the low carbonization of rural tourism and how to carry out the deficiencies effectively, which requires to establish a long-term mechanism of low carbon tourism education system. The village committee and the relevant department of tourism should be established a low carbon tourism education system which in accordance with Tian mu village" Happy Farmhouse "of the actual mechanism, including low carbon tourism education planning, to determine the leader of low carbon tourism education, low carbon tourism education object, the form of low carbon tourism education, the content of low carbon tourism education, put forward the guarantee measures low carbon tourism education and evaluate the achievement of 
low carbon tourism education, etc. Meanwhile, Tian mu village also should strengthen the construction of low carbon tourism education service points, low carbonization of rural tourism service points as the carrier of low carbonization of rural tourism should be made clear its composition, function attributes, operational mechanism and management regulations, etc., so as to promote the normal development of carbon tourism education.

\subsection{Strengthening rural tourism low-carbon tourism star standard construction}

Through the rural tourism low-carbon tourism star standard construction, can greatly improve the Tian mu village rural tourism willingness to accept low carbonization of rural tourism practitioners, thereby promoting low carbonization of rural tourism. Rural tourism low-carbon tourism star means rural tourism indicators based on low-carbon assessment of the extent of its division, determining carbon levels. Specific indicators include low carbon content rural tourism level waste disposal, equipment operation and management degree, the extent of low-carbon tourism services, construction of low-carbon tourism products and tourism product is the situation with multiple aspects of educational and other low-carbon. Low-carbon tourism -star standard construction can take environmental protection and " Happy Farmhouse " stakeholders combine to greatly facilitate " Happy Farmhouse " low-carbon tourism practitioners willingness education .

\section{Summary}

To build a low carbonization of rural tourism is an important way to implement a low-carbon economy, is also to put the low carbon tourism concept into practice, and the effective way to guide practice [7]. At present, the low-carbon tourism construction of Tian mu village is still in exploring stage, if can from the perspective of the ideological level, to improve the " low carbon concept of Happy Farmhouse " practitioners through education , improve the relevant tourism services, and has the scientific guidance for " Happy Farmhouse " low carbon tourism facilities and product development. It will play an important role to improve the Tian mu village " Happy Farmhouse " level of development and the promotion of " Happy Farmhouse " sustainable development; At the same time, the practice of Tian mu village of low carbonization of rural tourism will be provide valuable experience and reference to other areas to develop low carbon rural tourism construction, so as to promote the development of low-carbon tourism. And low-carbon tourism will also bring a new era of development for rural tourism in the development of our country, let us concern, think and act get together.

\section{Acknowledgements}

This work is supported by the projects: "Zhejiang rural tourism low carbon demonstration esearch".
(15JDNF02YB). Zhejiang province philosophy social sciences research base planning project.

\section{References}

[1] Hu Jianqiang, Shan Wenjun and Li Liang: Carbon Tourism Research Status and Prospects [J]. Zhejiang Shuren University, 2011.11(3):31 - 35

[2] Cai Meng: Theory and practice of low carbon Tourism -- a case in China, East China Normal University, 2012, http://www.cnki.com.cn/

[3] Wu Ying: Promote low-carbon tourism: a new opportunity for development agencies $[\mathrm{J}]$ economic and technological co-operation, 2010 (13):36- 37

[4] Feng Duo and Li Bin: The think of improving low-carbon economy of Happy Farmhouse Tourism Dapingan Village Xiaying town Ji country TiLin ann city as an example of low carbon economy [J] Agricultural Environment and Development, 2010 (6) : $59-61$

[5] Liu Wei and Yang Lei: Carbon Happy Farmhouse suburbs of Beijing Tourism Development Strategies [J]. Agricultural Sciences, 2012.51(20):4691 - 4696

[6]Zhou Jianfa: The current situation, problems and countermeasures of building a low-carbon rural areas[J]. Anhui Agricultural Sciences, 2012 (9):5640 5642.

[7] Al Bobby. Social research methods. Beijing: China Press.2009. 